\title{
GEOENVIRONMENTAL DEGRADATION IN THE PENINSULAR RIVER BASIN IN JHARKHAND, INDIA
}

\section{Degradação geoambiental nas bacias de rios peninsulares em Jharkhand, Índia}

\author{
V. C. Jha \\ Department of Geography, Visva-Bharati University Santiniketan \\ West Bengal, India \\ vcjha@asia.com
}

\author{
S. Saha \\ National Atlas and Thematic Mapping Organization \\ West Bengal, India \\ saha_diya@rediffmail.com
}

Artigo recebido para publicação em 26/04/2010 e aceito para publicação em 20/06/2010

ABSTRACT: Geoenvironmental characteristics of the Peninsular drainage basins in Jharkhand State of India is the result of endogenetic, exogenetic and anthropogenetic mechanisms. As the Peninsular landmass is the oldest land mass in its geomorphic history. Since pre-cambrian times the landmass is experiencing phases of aggradation and degradation. Recently, the man-induces mechanisms have also been dominating mechanisms in changing the surface morphology of the drainage basins. The role of weathering, mass movement and erosion is significant in reducing the strength of the landmass of such basins resulting environmental degradation in the basin landscape. Geoenvironmental factors are responsible in degrading the landmass ultimately affects the sustainability of the region. Among the geoenvironmental factors the engineering properties of the landscape like topography, drainage network, soil erosion, rockmass strength are more significant in identifying the terrain stability of the basin which causes the degradation. In this paper, an attempt has been made to analyse the engineering properties of the basin along with the other geoenvironmental factors to find out the status of degradation in the basin with a view to suggest a sound environmental management for the future development of region.

Keywords: Geoenvironmental Degradation. Morphoclimatic mechanisms. Rock mass strength. Terrain stability. Sustainable development and management.

RESUMO: $\quad$ As características geoambientais das bacias de drenagem peninsulares no Estado de Jharkhand na Índia são resultantes dos mecanismos endogenéticos, exogenéticos e antropogenéticos. A massa peninsular constitui a mais antiga massa terrestre de sua história geomórfica. Desde os tempos pré-cambrianos o território passa por fases de agradação e degradação. Recentemente, os mecanismos de indução humana também têm dominado os mecanismos de modificação da superfície morfológica das bacias de drenagem. O papel do intemperismo, dos movimentos de massa e da erosão é significativo na redução da energia da massa terrestre das bacias, resultando em degradação ambiental de suas paisagens. Fatores geoambientais são responsáveis pela degradação dos solos, que acabam por afetar a sustentabilidade da região. Entre os fatores geoambientais estão as propriedades de fisiografia da paisagem como 
a topografia, a rede de drenagem, a erosão dos solos, a dureza da rocha, que são muito importantes na identificação da estabilidade do terreno da bacia, que pode provocar degradação. Neste trabalho, uma tentativa foi feita para analisar as propriedades de fisiografia da bacia, juntamente com outros fatores geoambientais para descobrir o seu estado de degradação, a fim de sugerir uma boa gestão ambiental para o desenvolvimento futuro da região.

Palavras-chave: Degradação geoambiental. Mecanismos morfoclimáticos. Dureza da massa rochosa. Estabilidade do terreno. Desenvolvimento e manejo sustentável.

\section{INTRODUCTION}

No part of the earth surface is free from threats. It applies to the drainage basins of the Peninsular India also. The drainage basins of this region in India has been experiencing the deep level of Morphogenetic and Anthropogenetic Mechanisms irrespective of the endogenetic processes in the past. The whole process is ultimately degrading the environment and creating scarcity of food for the existing and future Population of the region. Environmental Management is all about judicious and gainful utilization of natural resources for socio-economic development as well as maintenance of environmental quality by proper usage of ecological principles. As a case study of the environmental management, the Sanjai River Basin has been selected. The basin environmental management involves the following stages.

(i) Present environmental status of the Sanjai River Basin.

(ii) The existing factors which obstruct the proper development of the basin and

(iii) Environmental planning of the basin, which leads to the socio-economic development of the region.

\section{OBJECTIVES}

The present study aims to analyse the geoenvironmental condition of the drainage basins of the Peninsular India. For this purpose, the Sanjai River basin has been selected with the following objectives.

(i) To analyse the physical characteristics of the drainage basin (ii) To identify the engineering properties responsible for the geoenvironmental degradation in region.

(iii) To find out the status of geoenvironmental degradation in the basin, and

(iv) To suggest some important measure for the Integrated Environmental Management.

\section{DATA SOURCES AND METHODODOLOGY}

The present investigation about the Peninsular India in general and the Sanjai River Basin in particular is based on mainly field work and the collection of soil and rock samples which were analysed in the geo-laboratories. Topographical Sheets, Satellite Imageries and other collateral materials have also been considered as data generating bases. Statistical and GIS based Cartographic Methods have also been followed for presenting the results.

\section{STUDY-AREA}

The Sanjai river is the tributary of river Subarnarekha (latitude, $22^{\circ} 46 /$ North to $22^{\circ} 39$ / North and longitude, $86^{\circ} 5 /$ East to $85^{\circ} 17 /$ East). It flows on the ancient Indian shild region of Chhotanagpur plateau. It dissected and sculpturing the landscape of Ranchi plateau. Sanjai river occupies small parts of East Singhbhum district and large part of the West Singhbhum district in Jharkhand state. Its catchment area is about $2,154 \mathrm{~km}^{2}$. The general elevation of the Sanjai river basin ranges from $140 \mathrm{~m}$ (extreme eastern part) to 992m (northwestern part) (FIGURE 1). 


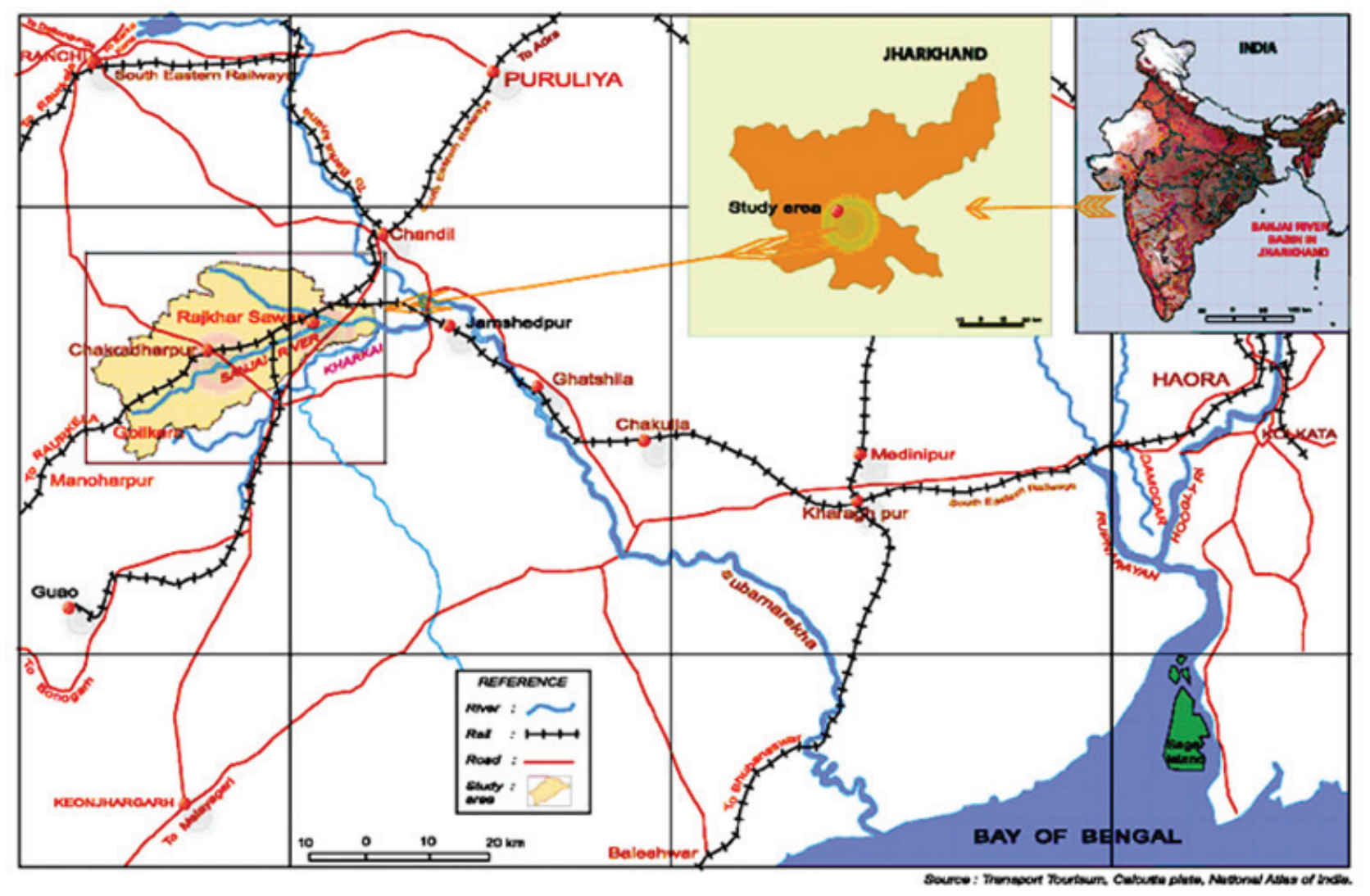

FIGURE 1: Study-area

\section{PHYSICAL CHARACTERISTICS OF THE BASIN}

Relief

The basin is demarcated in the north and western by the hills of Dalma and Porahat. In the south Saranda hills are located. In the south- eastern part of the basin Kolahan upland is situated. The Porahat Dalma range (elevation 450 to 950 meters above mean sea level) run from east west with slight northward convexity. In northern part of the Sanjai basin water divides (Dalma and Porahat hills) separated Kharkai river (main tributary of the Subarnarekha river) from Sanjai river. In western part and the southwestern part the hills divides Sanjai river from South Koel (another tributary of the river Subarnarekha). In eastern part and southeastern part water divides Kharkai river from Sanjai river. In addition to the mentioning primary water divider, there is a number of secondary and tertiary divider with in the basin that separates the tributary basins of Sanjai river basin from one another. This basin and its adjoining terrain forming a major part of the singhbhum plain but most of the areas are plateau like upland that rises gradually west and northwards from the Subarnarekha valley. There are numerous hills which are almost parallel to the Dalma-Porahat ranges (above $750 \mathrm{~m}$.), most famous are Raisindri Pahar (800 m.), Kuti Buru (800 m.), Lukud Buru (918 m.) etc.

\section{Absolute Relief}

Absolute relief is referred to as the maximum elevation of a unit area above the sea level. It is very important in delineating the terrain morphology as well as the existence of erosion surfaces. The absolute relief of Sanjai River Basin is obtained by a square grid with unit area of $1 \mathrm{~km}^{2}$ and noting the maximum height of each square with the help of contours and spot height. Obtained values range from $138 \mathrm{~m}$ to 
915m (north western part of the basin and western part of the village Dodarda). The study area is clas- sified into the following categories of absolute relief

(TABLE 1).

TABLE 1: Distribution of Absolute Relief

\begin{tabular}{c|c|c|c}
\hline \multicolumn{1}{c}{ Symbols } & A rea $\left(\mathrm{km}^{2)}\right.$ & A rea (\%) \\
\hline$<200$ & Arvl & 256 & 14.2 \\
$200-300$ & Arl & 718 & 31.01 \\
$300-400$ & Arm & 350 & 16.25 \\
$400-500$ & A rmh & 276 & 12.81 \\
$500-600$ & A rh & 390 & 18.11 \\
$>600$ & A rvh & 164 & 7.61 \\
& & 2154 & 100 \\
\hline
\end{tabular}

The spatial distribution of the absolute relief has been categorized into six groups. These categories are mentioned here below.

Very low absolute relief ( $<\mathbf{2 0 0} \mathbf{~ m}$, Arvl): The lowest absolute relief category (less than $200 \mathrm{~m}$ ) covers $256 \mathrm{~km}^{2}$ or 14.2 percent of the study area. It is well marked in the southeastern part of the basin. Two patches are also seen over the flat summits of the Dalma and porahat hills.

Low absolute relief (200m-300m, Arl): The area is restricted to the gentle sloping Singhbhum plain covering most of the tributary basins of the Sanjai River viz. Sona nadi, Sialjoro Nala, Gobri Nadi, Kuchai Nala, Bamni Nadi (except upper part).

Moderate absolute relief (300m-400m, Arm): It covers $350 \mathrm{~km}^{2}$ or 16.25 percent of the basin area is found in the upper part of the Sona and Bamni nadi, the lower part of the Jatra Gara and gachhkara Nadi lying on the foot slope of the Singhbhum highland tract.

Moderately high absolute relief $(400 \mathrm{~m}-500 \mathrm{~m}$, Armh): This group covers $276 \mathrm{~km}^{2}$ or 12.81 percent of the basin area. It is confined to the said highland tract including Sona Nadi (northern part), Bamni Nadi (northwestern part), Jatra Gara (western part), Gachhkara Nadi (southern part). This category is mostly visible in a narrow continuous strip on the fringe of the Sanjai Basin excluding its eastern flank. It is actually typical of the existing convexo-concave hill slope.

High absolute relief $(500 \mathrm{~m}-600 \mathrm{~m}$, Arh): It is covering $390 \mathrm{~km}^{2}$ or 8.11 percent of the basin area. It is well marked in the upper part of the Sona Nadi, upper part of the bamni nadi , large part of Jatra Gara Nadi ,Gachhkara Nadi and the upper Toya Gara (gara means nadi) basins.

Very high absolute relief (above 600m, Arvh): The highest absolute relief with its areal coverage of $164.0 \mathrm{~km}^{2}(7.61 \%)$ comprise the crest parts of the following residual hills and ranges (burus and dungris in the north located Khanda Buru (696m), Raisindri Pahar (680m), Dereya Buru (644m) etc.; in the north east located Sira Buru (462m), Jamda Buru (480m); in the south east located Ramiya Buru (555m), Bejay Buru (685m) etc.; Mat Buru (642m), Bicha Buru $(709 \mathrm{~m})$, Lota Pahar (746m) etc. located in the west.

\section{Drainage}

The Sanjai River is the consequent stream of the study-area. It flows from west to east direction. Its total length is $6447 \mathrm{~km}$ from source to mouth. It has eight important tributaries and other innumerable small tributaries (FIGURE 2). 


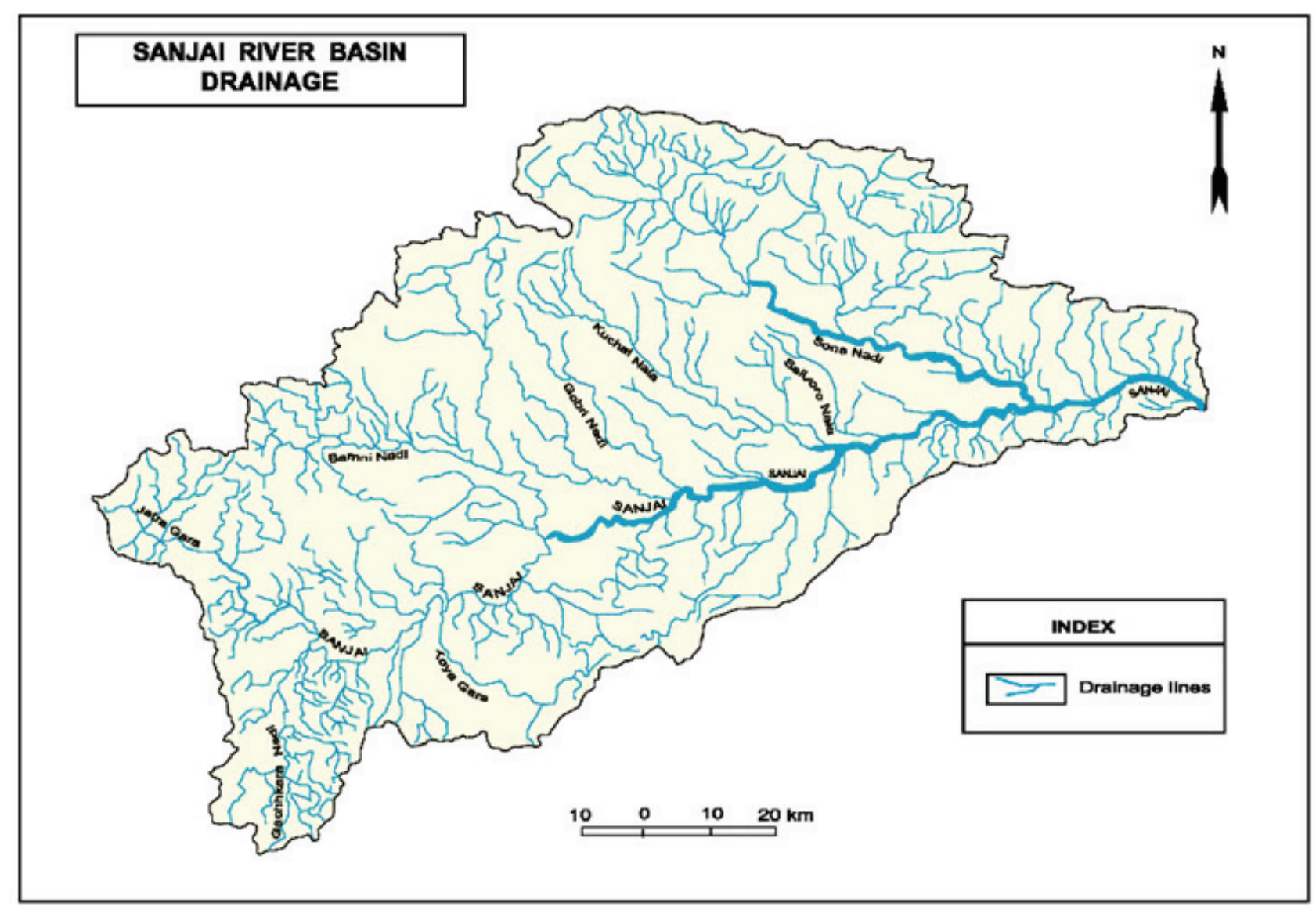

FIGURE 2: Sanjai River Basin - Drainage

A brief description of all eight important tributaries are given here below:

Sona Nadi: The Sona is the main tributary of Sanjai River. It flows from the northwest to southeast direction. Sona and other tributary of Sanjai, Sonhua are famous for placer gold in their beds. In the recent past Sona was one of the source of gold in the Subarnarekha basin. There are 6 tributary strea$\mathrm{ms}$ of the Sona nadi viz. Parambera nadi, Suru nala, Bapra nala, Kulachaki nala, Ragra nala, Bapra nala. Some notable peak of this basin area Raisindri Pahar (680m), Khanda Buru (696m), Marang Buru(887m) etc. Sonpet dome is located in the northwest part of the Sona valley this area is kown as "Sonapet valley". Annular pattern of drainage is developed here. Rectangular pattern of drainage is also developed in Dalma and Porahat ranges of the basin. Structural control is the prime factor which influencing the course of the river. The course of the Sona is remarkable parallel.
The length of this river is $1716 \mathrm{~km}$. And it is left bank tributary of river Sanjai. Point bar deposit, Paired terraces are the remarkable fluvial forms of the river Sona. It is sixth order tributary of the Sanjai River.

Bamni nadi: It is another main tributary of Sanjai river. It flows from northwest to south direction and join the main river. Bijai is the main tributary of Bamni nadi. It is left bank tributary of Sanjai river. Length of the river is $920 \mathrm{~km}$. It is sixth order tributary of the Sanjai river.

Jatra gara: Jatra gara is a important tributary of Sanjai. It originates from extreme western hilly part of the basin. It has a total length of $25 \mathrm{~km}$. It flows in easterly direction and join the Sanjai river. The stream has a basin area of about $84 \mathrm{~km}^{2}$.

Gachhkara nadi: Gachhkara dam is the only dam of the basin, which constructed on this river. It flows in a northerly direction. This stream has a basin area about $117 \mathrm{~km}^{2}$. Fishing, boating and other recre- 
ation facilities are available in Gachhkara dam.

Toya gara: Toya gara is only $41 \mathrm{~km}$. length. It is a fault-guided stream. This stream has a basin area about $70 \mathrm{~km}^{2}$. It flows in a northerly direction.

Gobri nadi: Gobri nadi is $44 \mathrm{~km}$. length. It flows in southerly direction. It is a left bank tributary of Sanjai. It has a basin area of $72 \mathrm{~km}^{2}$.

Kuchai nala: Kuchai nala is a left bank tributary of Sanjai. It flows in a southerly direction and join the trunk stream. It has a total length of $72 \mathrm{~km}$. and a basin area of $166 \mathrm{~km}^{2}$.

Sialjoro nala: Sialjoro nala is a small stream only $30 \mathrm{~km}$. length. This stream has a basin area of $32 \mathrm{~km}^{2}$ mostly composed of singhbhum group pelites, mafic bodies and soda granites.

\section{Soils}

The soil is the product of environmental and biological processes and it is interrelated with climate, vegetation (flora), animals (fauna), underlying rocks, physiography and time. Major geomorphic features of the basin are hilly terrain, undulating upland, undulating plateau and valleys.

There are 9 types of soil in the basin. They are as follows:

i. Loamy soil on hilly slope.

ii. Gravelly loamy soil on very low slope.

iii. Loamy soil on hilly to moderate slope.

iv. Loamy soil on gentle slope.

v. Shallow loamy soil on gentle slope.

vi. Loamy sand soil on gentle slope.

vii. Clayey soil on very gentle slope.

viii. Clayey soil on very low slope.

xix. Clay-loam soil on gentle slope.

\section{Vegetation}

Vegetation plays a major intermediately role between landforms and climate. This basin occupies deciduous forest. They differ in place to place in relation to topography, slope, elevation, rocks, regoliths and soils. The forest attracts precipitation and arrest soil erosion and runoff. But most part of the basin forest covered has been removed or destroyed by human interference. So this basin suffer various proble- $\mathrm{ms}$ like soil erosion, dissection of the area, lowering of the water tables, less rainfall and rapid wash of the upper layers of the soil. The wets deciduous are limited in the north and northwest part of the basin. The common trees re Sal mixed with Bamboos, besides a host of other deciduous trees. The dry deciduous forest occupies rest of the area. The nature of forest is dense to fairly dense and open mixed forest

There are mainly four types of forest is prominent in the basin. Dense forest covered mainly in upper part or hilly part of the basin. Sal and mixed forest of deciduous species are very prominent. Some part of the hilly portion and adjoining part are under the protected forest. Open forest are found mainly foothills zone. In the past they are cover with thick forest but nowadays-local inhabitants excessively and unscientifically exploited it. Main plants are $\mathrm{Bu}-$ tea, Khajur, Tar, Bamboo, palash , kusum etc. Scrubs are found in small patches of the basin. Some parts of the granite hills are barren and somewhere covered with thin layer of soil. Scrubs and bushes chiefly some chasmophytes are found in this part of the basin. Some dome shaped hills are completely barren and some are covered with a few small trees. Lantana and other exotic weeds are seen here. Degraded forests are found mainly undulating plateau and plain area of the basin. It occupies vast area of the basin. Here cultivation is the main cause of deforestation.

The landscape of the Sanjai river basin is polygenetic in origin. This basin has been exposed to subaerial erosion since Precambrian period to the present Pleistocene period. So this basin bears the imprints of several cycles of erosion. The Sanjai river forms steep gorges in the northern and the western parts of the basin and it also give rise to number of springs in the western part. Most conspicuous feature of the Sanjai is its topography, which include mature topography and late mature topography in the same valley.In the present basin major rocks are of metamorphic variety viz. Schists, Phyllites etc. Ignious rocks, viz. granite, basalt, tuff etc. are also very prominent in this basin.

\section{Geomorphic Units (Topography)}

This unit shows topographic characteristics of the Sanjai River Basin. They are as follows: 
Hill Ranges:Dalma and Porahat hills encircle northern, western and southern part of the basin. These hills are in dissected phase. There are two main causes of dissection (i) fluvial action and (ii) repeated earth movement. Dome shaped hills and elongated hills are the result of this two actions. The elevations of hill ranges vary from $240 \mathrm{~m}$ to above $800 \mathrm{~m}$ (FIGURE 3).

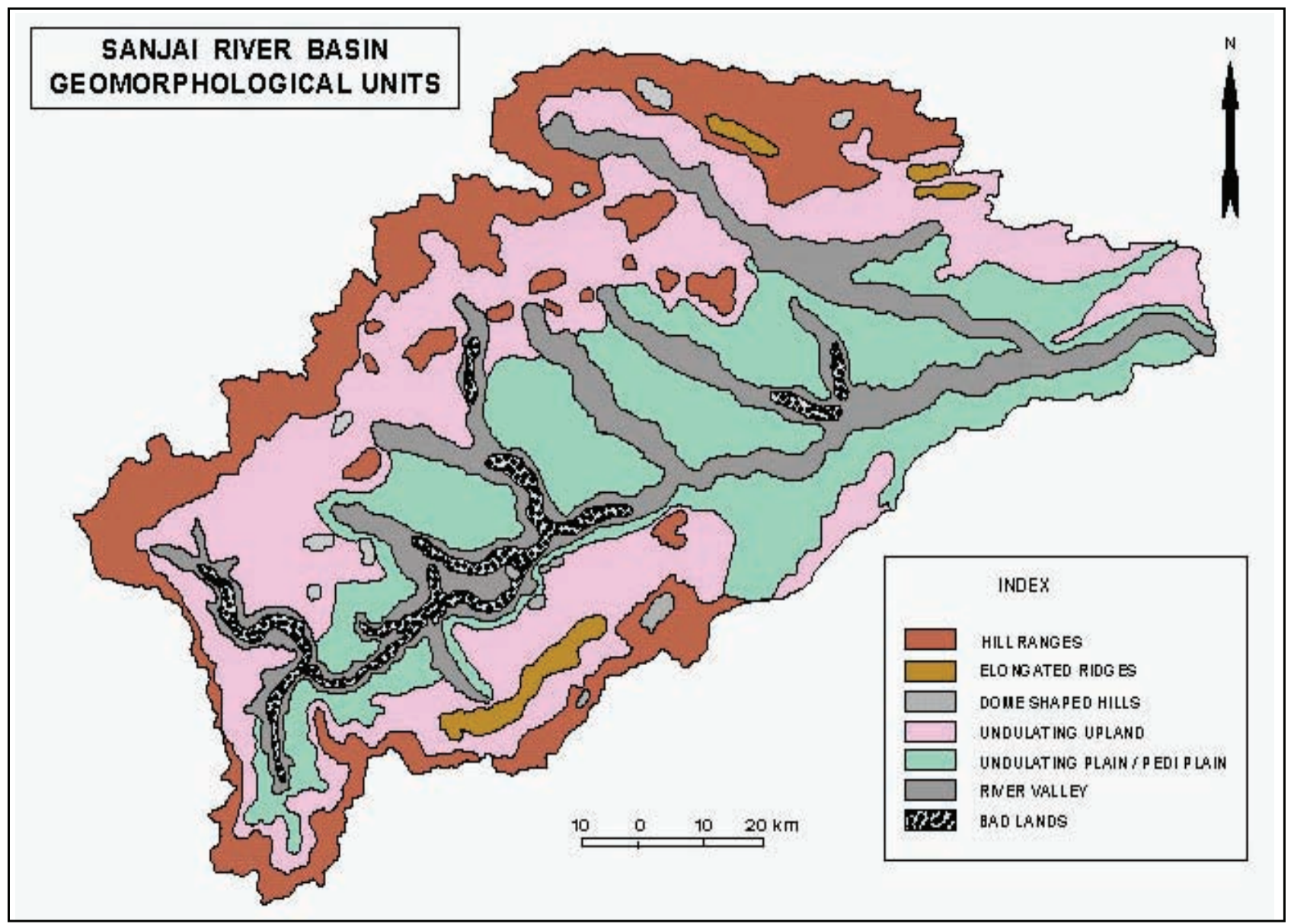

FIGURE 3: Sanjai River Basin - Geomorphological Units

Elongated Ridges: Elongated hills are located in southern part, (near Toya gara, right bank tributary of Sanjai), northern and northeastern parts (upper part of Sona nadi, left bank tributary of the main stream) viz. Birkuti Buru (520m), Bejay Buru(685m), Ganti Buru(640m) in the southern part of the basin and Raisindri pahar (680m), Khanda Buru (696m) in the northern part of the basin. They are mainly formed by maffic lava, quartzite and granite gneiss rock. They are known as residual hills.

Dome Shaped Hills: Dome shaped hills are located in the northern and northeastern part of the basin. These hills are known as erosional platforms (Mukhapodhyay,1980, p.182). According to Mukhopadhyay these hills are outcome of the multiple erosion cycles with repeated earth movement since tertiary periods to recent time. They are mainly ofgranite origin and residual in nature. For example Lukud buru ( $817 \mathrm{~m})$, Kuda buru (687m), Dulma Buru (665m) etc. located in the western part of the basin (FIGURE 3).

Undulating Upland: Wide plateau areas with elevations vary from 250 to 400 meters. This part of the basin has moderate relief and moderate to moderately steep slope, with granite tor landform. 
Unddulating Plain or Pediplain: Undualting plain or pediplain is mainly by formed mainly dissection of plateau surface. So the Sanjai plain is different from normal plain. Interesting features of the rolling plain are buru (small isolated hill or inselberg) or dungris which are projected all over the plain surface.

River Valley: The river valley of Sanjai river basin is also significant. In almost all the important tributaries and main stream of the basin river terraces are prominent. Another feature is point bar deposit, mainly found on Sona nadi (Plate II, XI and XII). According to Thornbury, "theses terraces reflect periods of rejuvenation which have affected streams". Nature of the terraces are alluvial in character and consist of gravel, sand and finer alluvium. These terraces are known as valley plain terraces, according to Leopold,Wolman and Millar (SATPATHI,1981, p.180). These terraces are the 'surviving parts of former continuous valley flood plain. The terraces of this basin are tectonic in origin and influenced river system. Some prominent terraces have been shown west of Chakradharpur in the Sanjai river basin.

Badlands: Badland topography is seen mainly in southern (west of Chakradhrpur in Sanjai river ba$\sin$ ), \& western parts (in Jatra-garaa basin). It is also found in smaller parts on the central part of the basin. Main causes of badland formation are (i) weak rocks (phyllite, schist, etc.) (ii) extensive erosion by numerous channel and rills, mainly in rainy season (they are developed due to occasional rainstorm). (iii) due to liner fluvial erosion formed narrow undulating ridge like gullies and ravines (iv) as a result the ground surface become uneven.

\section{Slope}

Slope is upward and downward inclination of surface between hills and valleys and form most significant aspect of landscape assemblages (SINGH, 1998). Nearly all the land surface slopes are in one direction. Slopes are the fundamental type of landscape features (KING, 1967). Slope is a function of relief

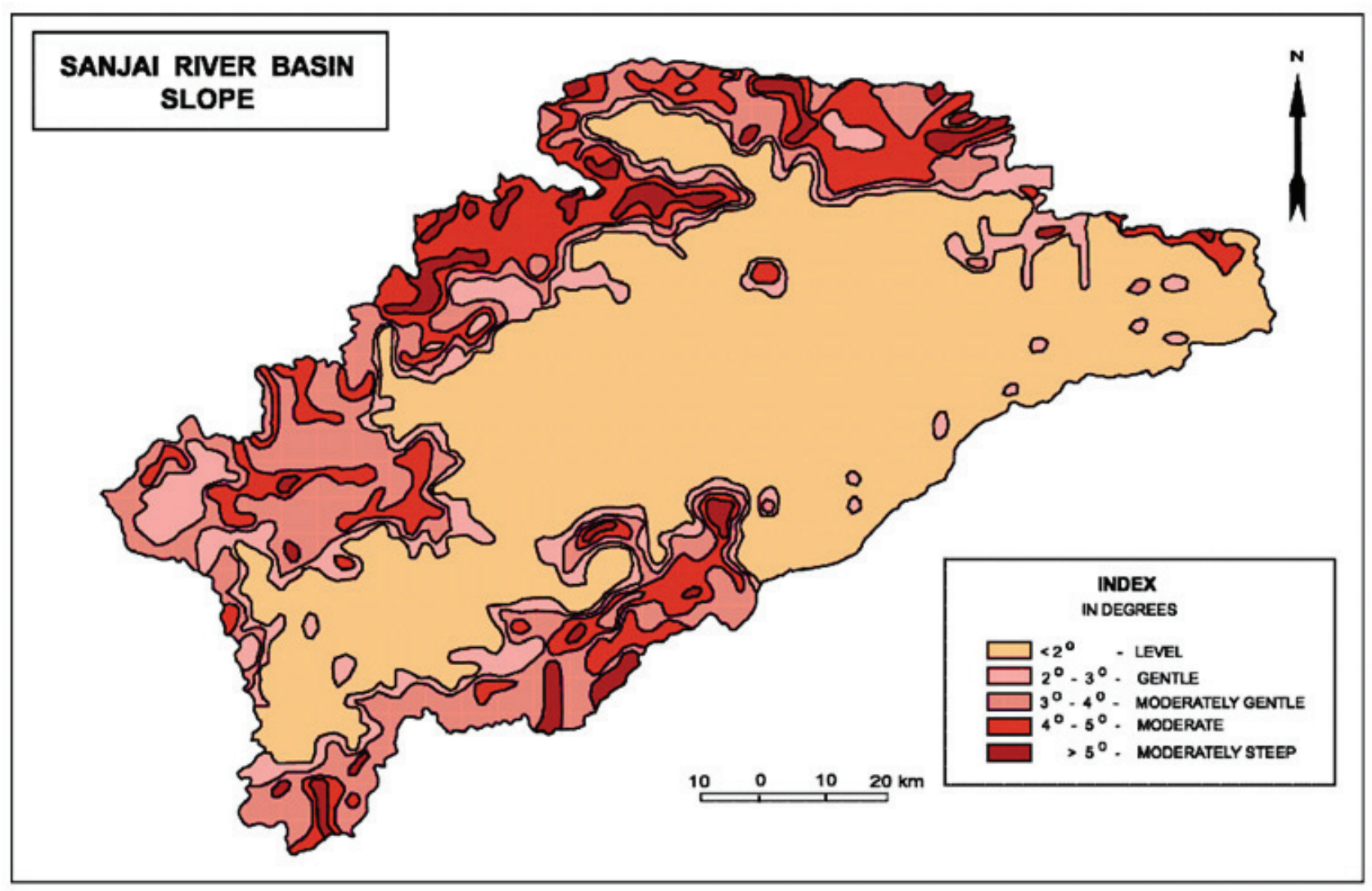

FIGURE 4: Sanjai River Basin - Slope 
inclination (PRASAD, 1988). The magnitude of slope may provide considerable inferences about the corresponding characteristics of the absolute relief, relative relief, dissection index and the drainage network in combination with the climate, rock type, structure, resistance, vegetation, soil.

Significant contribution has been made by Wentworth (1930), Horton (1945), Strahler (1950), King (1953), Schumm (1956, 1967), Singh \& Pandey (1986) and others. In the present study, Wentworth's technique has been adopted to determine the average slope of the Sanjai Basin. The slope values of each square grid of the Sanjai River basin vary from $6^{\prime}$ to $6^{\circ} 9^{\prime}$. These values are arranged into five categories, ranging from below $2^{\circ}$ to above $5^{\circ}$ (FIGURE 4).

According to the TABLE 1 maximum percentage of slope area $(50.79 \%)$ falls under the category of level slope (less than $\left.2^{\circ}\right)$. Gentle slope $\left(2^{\circ}-3^{\circ}\right)$ accounts for 18.34 percent of the basin area. Moderately gentle slope $\left(3^{\circ}-4^{\circ}\right)$ occupies 16.25 percent of the basin area. Moderate slope $\left(4^{\circ}-5^{\circ}\right)$ occupies 10.21 percent of the basin area. Moderately steep slope (above $5^{\circ}$ ) occupies only 4.41 percent of the basin area (TABLE 2).

TABLE 2: Areal distribution of slope categories

\begin{tabular}{ccccc}
\hline Slope categories in degrees $\left(^{\circ}\right)$ & A rea $\left(\mathrm{km}^{2}\right)$ & $\%$ & Slope type & Symbol \\
\hline$<2^{0}$ & 1094 & 50.79 & L evel & $\mathrm{SI}$ \\
$2^{0}-3^{0}$ & 395 & 18.34 & Gentle & $\mathrm{Sg}$ \\
$3^{0}-4^{0}$ & 350 & 16.25 & M oderately gentle & $\mathrm{Sgm}$ \\
$4^{0}-5^{0}$ & 220 & 10.21 & M oderate & $\mathrm{Sm}$ \\
$>^{0}$ & 95 & 4.41 & M oderately steep & $\mathrm{Sms}$ \\
& 2154 & 100 & & \\
\hline
\end{tabular}

The distribution pattern of slope (TABLE 1) shows that 50.79 percent of the basin area has very gentle slope. Moderately gentle slope characterizes about 18.34 percent of the basin area. Gentle slope accounts for 16.25 percent of the basin area. But the moderate slope and moderately steep slopes accounts for only 10.21 percent and 4.41 percent of the basin area respectively.

Level slope (Sl, less than $2^{\circ}$ ): The slope categories of the Sanjai river basin reveal the fact that most of the area $\left(1094 \mathrm{~km}^{2}\right.$ or $\left.50.79 \%\right)$ is characterized by level slope (less than $2^{\circ}$ ). Infact the Singhbhum plain corresponds to the lower values of absolute relief, relative relief, dissection index, drainage frequency and drainage density is typified by this group. Deviation is observed in the area where it is infested by the rill and gully erosion.

Gentle slope ( $\mathrm{Smg}, \mathbf{2}^{\mathbf{0}}-\mathbf{3}^{\mathbf{0}}$ ): Gentle slope shares 18.32 or $395 \mathrm{~km}^{2}$ of the basin area. It is associated with the narrow belt of foothills zone especially in the northern, western and southern fringe of the basin.
But it is totally absent in the eastern part of the basin. This slope type occupies upper valley of Sona nadi, Bamni nadi, lower valley of Jatragara, middle valleys of Gachhkara nadi and Toyagara nadi. Gentle slope is noted in small isolated patches on hills or burus in the southeastern flank of the study area.

Moderately Gentle slope (Smg, $3^{\circ}-4^{\circ}$ ): Gentle slope categories occupies $350 \mathrm{~km}^{2}$ or 16.25 percent of the basin area. It is rerstricted to the foot slope (pediment) of the Porahat highland (the Dalma Dhanjori ract) in a very narrow strip covering the basins of Sona Nadi, Bamni nadi, Jatra gara, Gachhkara nadi Toya Gara, some patches of gentle slope are also noticed over the summit of the Porahat highland in the north. This category is also totally absent in eastern part. This area is mainly undulating plateau of the $b$ $\sin$.

Moderate slope (Sm, $\left.4^{\circ}-5^{\circ}\right)$ : Moderate slope occupies only $220 \mathrm{~km}^{2}$ or 10.21 percent of the basin area. It is profound mainly in Dalma and Porahat hills. It is found scattered in the north, northwest and 
south of the basin. Residual hills viz. Sonpet dome, Raisindri Pahar and dissected scarps belong to this category. This category is present on bare or forested summits of the residual hills and ridges of the Dalma and Dhanjori lava.

TABLE 3: Co-relation Between Frequencies Distribution of Slope and Absolute relief

\begin{tabular}{|c|c|c|c|c|c|c|c|c|c|c|c|c|}
\hline \multicolumn{3}{|c|}{ A bsolute relief in meters } & \multicolumn{10}{|c|}{ Slopes in degrees } \\
\hline & & & $<1$ & $1-2$ & $2-3$ & $3-4$ & $4-5$ & $>5$ & & & & \multirow[b]{3}{*}{ fux.uy } \\
\hline- & - & $X$ & 0.5 & 1.5 & 2.5 & 3.5 & 4.5 & 5.5 & \multirow[b]{2}{*}{ fy } & \multirow[b]{2}{*}{ fy.uy } & \multirow[b]{2}{*}{$f y \cdot u^{2} y$} & \\
\hline - & $Y$ & UY/UX & -2 & -1 & 0 & 1 & 2 & 3 & & & & \\
\hline$<200$ & 150 & -3 & 242 & 10 & 4 & - & - & - & 256 & -768 & 2304 & 1482 \\
\hline $200-300$ & 250 & -2 & 679 & 32 & 7 & - & - & - & 718 & -1436 & 2872 & 2780 \\
\hline $300-400$ & 350 & -1 & 184 & 105 & 49 & 12 & - & - & 350 & -350 & 350 & 461 \\
\hline $400-500$ & 450 & 0 & 39 & 75 & 119 & 28 & 15 & - & 276 & 0 & 0 & 0 \\
\hline $500-600$ & 550 & 1 & 8 & 10 & 195 & 139 & 36 & 2 & 390 & 390 & 390 & 191 \\
\hline$>600$ & 650 & 2 & 1 & 13 & 18 & 84 & 39 & 9 & 164 & 328 & 656 & 348 \\
\hline \multicolumn{3}{|c|}{$f x$} & 1153 & 245 & 392 & 263 & 90 & 11 & 2154 & -1836 & 6572 & 5262 \\
\hline \multirow{2}{*}{\multicolumn{3}{|c|}{$\begin{array}{l}\text { fxux } \\
\text { fxu } \\
\end{array}$}} & -2306 & -245 & 392 & 263 & 180 & 33 & \multirow{3}{*}{\multicolumn{4}{|c|}{$\begin{array}{l}=-2075 \\
=5579 \\
=5262\end{array}$}} \\
\hline & & & 4612 & 245 & 0 & 263 & 360 & 99 & & & & \\
\hline \multicolumn{3}{|c|}{ fxxuy } & -4516 & 63 & 0 & 293 & 228 & 60 & & & & \\
\hline
\end{tabular}

Bivariate correlation coefficient $=+0.83$

Moderately Steep slope (Sms, above $5^{\circ}$ ): Steep slope covers very small only $95 \mathrm{~km}^{2}$ or 4.41 percent of the basin area. All the 'burus' (hills) like Sada buru (880 m.), Bisna buru (795 m.), Lukud buru (817 m.), Bicha buru (709), etc. come under this category. This category is found in small patches of the northern part of Dalma-Porahat hills (upper reaches of Sona nadi), in western part Porahat hills (upper reaches of Bamni nadi and Jatra gara) and southern part of hills (upper reaches of Gachhkara nadi and Toya gara). Escarpments, scarp faces, granite dome quartzite ridges and flat topped sharp edged dissected Dalma trap are typical of this category. Generally the first and the second order streams are common in this area.

The slope of the surface is the result of various factors like absolute relief, relative relief, drainage density, climate, geology, tectonic activities etc. Level slope cover most area of the basin $(50.79 \%)$ and this category characterizes low absolute relief, low relative relief, low dissection index low drainage frequency and coarse drainage density. The coefficient of correlation between slope and absolute relief is +0.83 (TABLE 3 ). The value is positive, it means when slope increases absolute relief also increases.
The ' $r$ ' value $(\mathbf{+} \mathbf{0 . 8 3})$ indicates old topography of the basin (Jha, 1996, p.154).

\section{Geology and rock strengths}

Rock strength of the Sanjai river basin depicted by terrain stability zone. There are three zones in Sanjai river basin viz. (i) Low rock mass strength (compressive strength of below $90 \eta / \mathrm{mm}^{2}$ (ii) Medium rock mass strength zone (compressive strength of 90$170 \eta / \mathrm{mm}^{2}$ ) (iii) high rock mass strength (above 170 $\eta / \mathrm{mm}^{2}$ ) (FIGURE 5). Compressive strength indicates amount of force, which a rock can withstand before getting brittle. So with progressive strength the rocks become ductile. $\eta$-Means Newton (force per unit). Per $\mathrm{mm}^{2}$ means square millimeter. Maximum area of the basin is under medium rock mass strength zone (90-170 $\left.\eta / \mathrm{mm}^{2}\right)$. The central part of the basin, mainly the Singhbhum shear zone, falls under low rock mass strength (below $90 \eta / \mathrm{mm}^{2}$ ). This zone resists less stress. High rock mass strength zone (above $170 \eta$ / $\mathrm{mm}^{2}$ ) covers extreme northern part Dalma-Porahat hilly zone, northwestern part and western parts including the source region of Sanjai River. High resistan- 
ce zone also exists in a narrow strip on the southern part of the basin and in a small elongated strip of eastern part of the basin. This part mainly comprises hilly portion formed by basic rock. This portion falls under poor developed area due to high elevation and lack of communication facilities.

Engineering geomorphology units of the Sanjai river basin have been prepared by the superimposed images of the engineering properties viz. geomor- phological units, geology units, rock strength units, slope units, soil erosion units, etc. (FIGURE 6). It deals with the geomorphic aspects of the Sanjai river basin. The results are very remarkable in sustainable land management (SLM) including land degradation and desertification as well as for obtaining a better planning system (Jha,2003,p.316). So it is a composite unit and it depicts morphological and engineering properties of the basin.

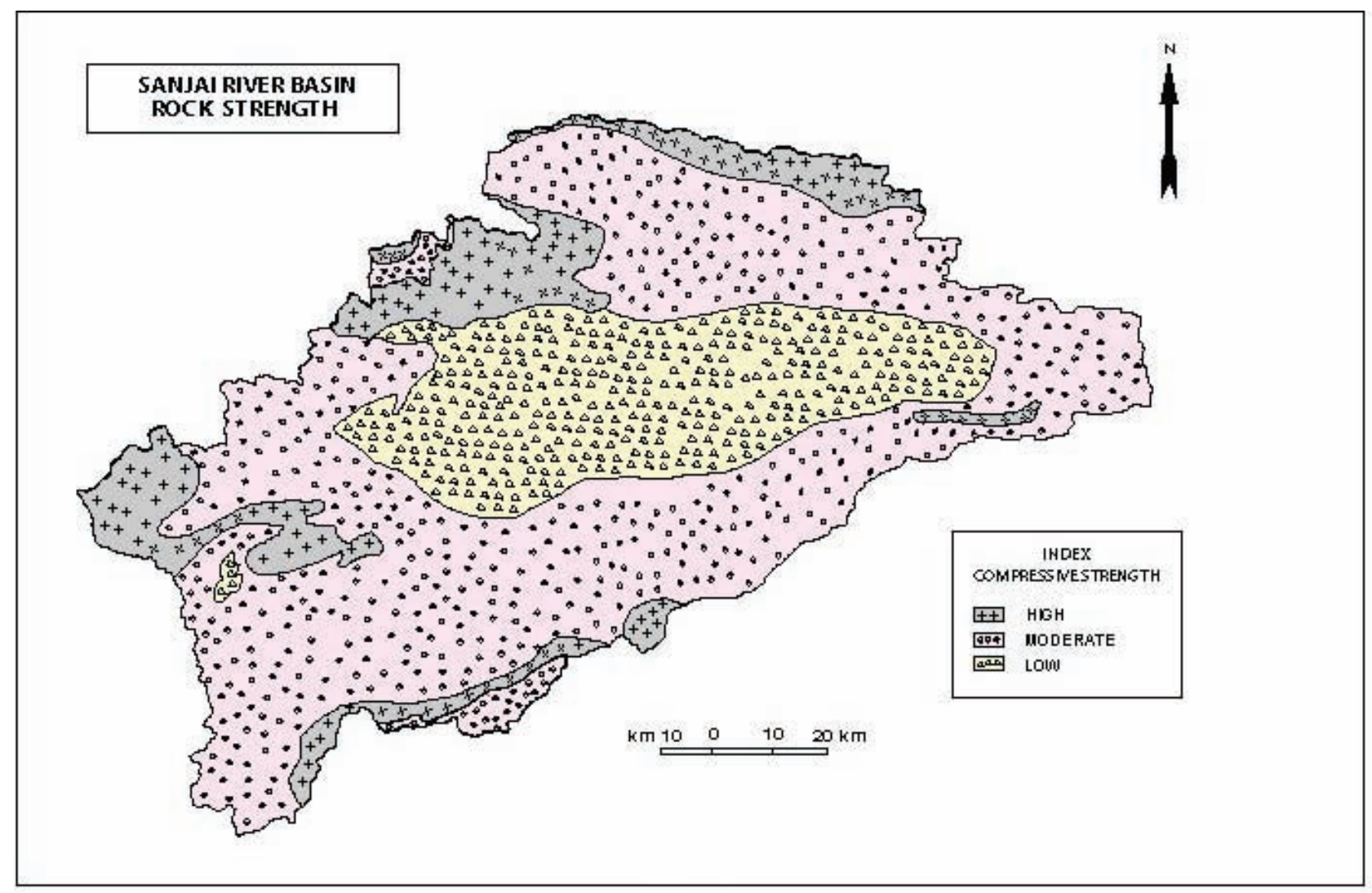

FIGURE 5: Sanjai River Basin - Rock Strength

The parameters used for preparation of engineering geomorphology units are (i) geology (ii) rock strength units (ii) geomorphology (Topography ) (iii) slope (iv) Soil erosion (v) vegetation. Superimposing of these layers and using GIS can divide the basin area into three major categories. They are:

(i) Low rock mass strength units (Rlo)

(ii) Medium rock mass strength units (Rme)

(iii) High rock mass strength units (Rhi)
These units show that all the parameters are interrelated in the study area. It gives terrain stability zones as a result (FIGURE 5). They are:

(i) Meta stable or Moderately Stable Zone

(ii) Unstable Zone

(iii) Stable Zone

Medium rock mass strength indicates a Meta stable zone and developmental work may be made. 
In the central part of the basin mainly the Singbhum shear zone falls under the low rock mass strength (below $90 \eta / \mathrm{mm}^{2}$ ). This zone resists less stress, so it is the unstable zone of the basin. This region is unsuitable for any kind of heavy constructional work (industry, dam etc.). So it becomes a less developed area of the basin. High rock mass strength area falls under poor developed area due to high elevation and lack of communication facilities. It also exist in a narrow strip on the southern part of the basin and in a smaller elongated shape in eastern part of the basin. This part is mainly hilly portion and formed by basic rock and is also a comparatively stable area of the basin.

\section{STATUS OF GEOENVIRONMENTAL DEGRADATION}

\section{Soil Erosion}

The landform of the Sanjai river basin is the result of both exogenetic and endogenetic processes. The basin area is covered with thick layer of soil. This soil is weathered from its rocky surface. This basin is good example of polycyclic landscape. Landscape of the basin has records of repeated earth movement as well as climatic changes. So the surface of the basin retains both fossil erosion surface and active erosion surface (FIGURE 6).

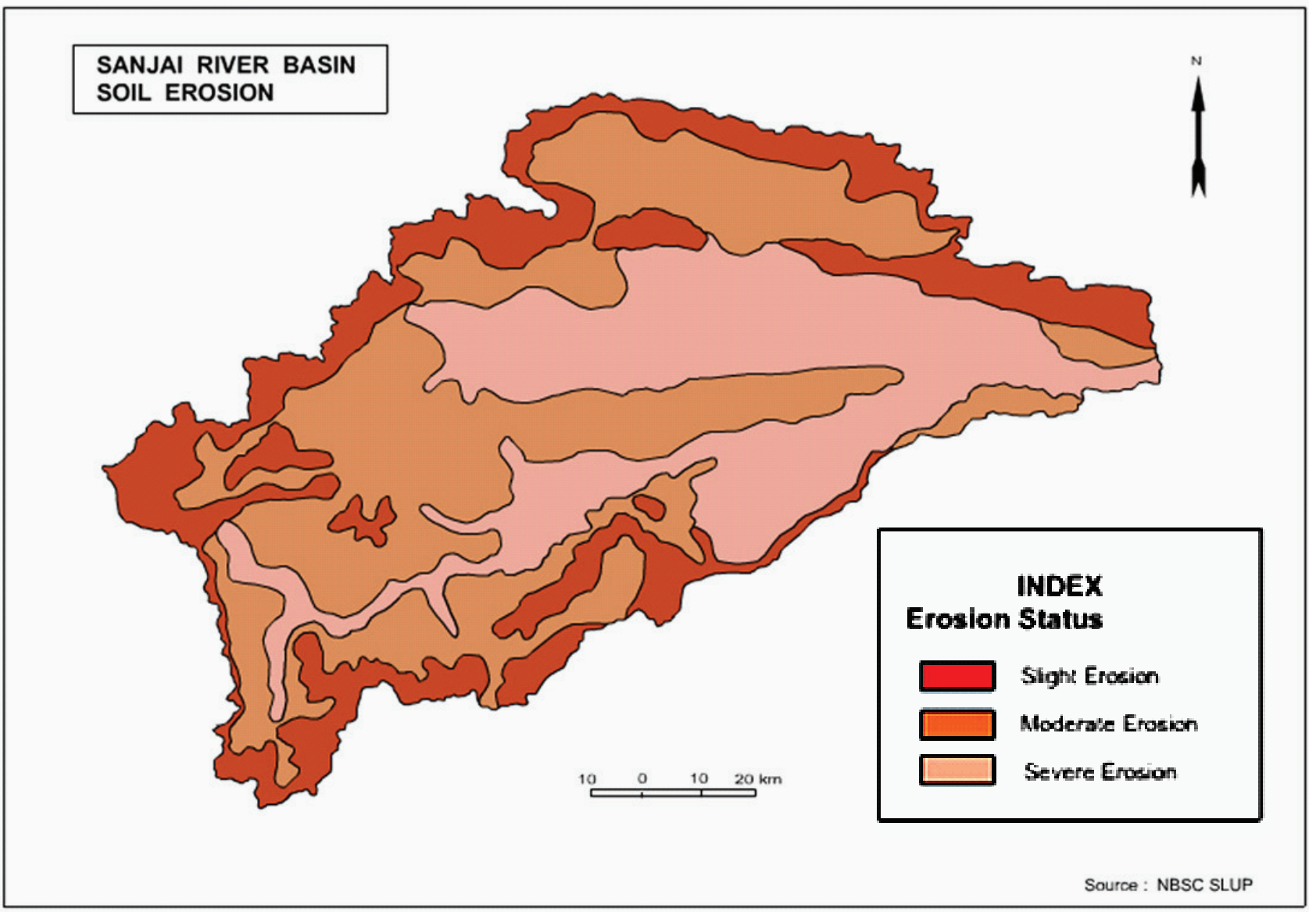

FIGURE 6: Sanjai River Basin - Soil Erosion

Soil degradation is often related to decline in soil quality (Sehgal,2000,p.14), caused by its misuse by humans. It means decline in the soil's productivity. According to Oldeman-Ed. (1988) soil degradation is a process, which lowers the current and futu- re capacity of the soil to produce goods or services. Environmental degradation indicates (Singh,1998, p.323) overall lowering of environmental qualities at local, regional and global scales by both natural processes and human activities. For example, volcanic 
eruptions, earthquake, cyclones, landslides, forest fires etc. are the natural factors, which destabilize the ecosystem of a particular area and thus cause environmental degradation. There are three types of degradation prominent in the basin viz.(i) Natural degradation (ii) anthropogenic degradation (iii) biological degradation (FIGURE 7). Natural degradation of the basin can be divided into two types (a) ravine erosion (b) sheet erosion. Ravine erosion is very prominent in the southwestern part near Sonua village, northern part in sona nadi basin near Kharsawan, central and some in the eastern part of the basin. Most interesting feature of ravine erosion is that the forest clad hilly areas are relatively free from erosion compared to the areas of gentler slopes.

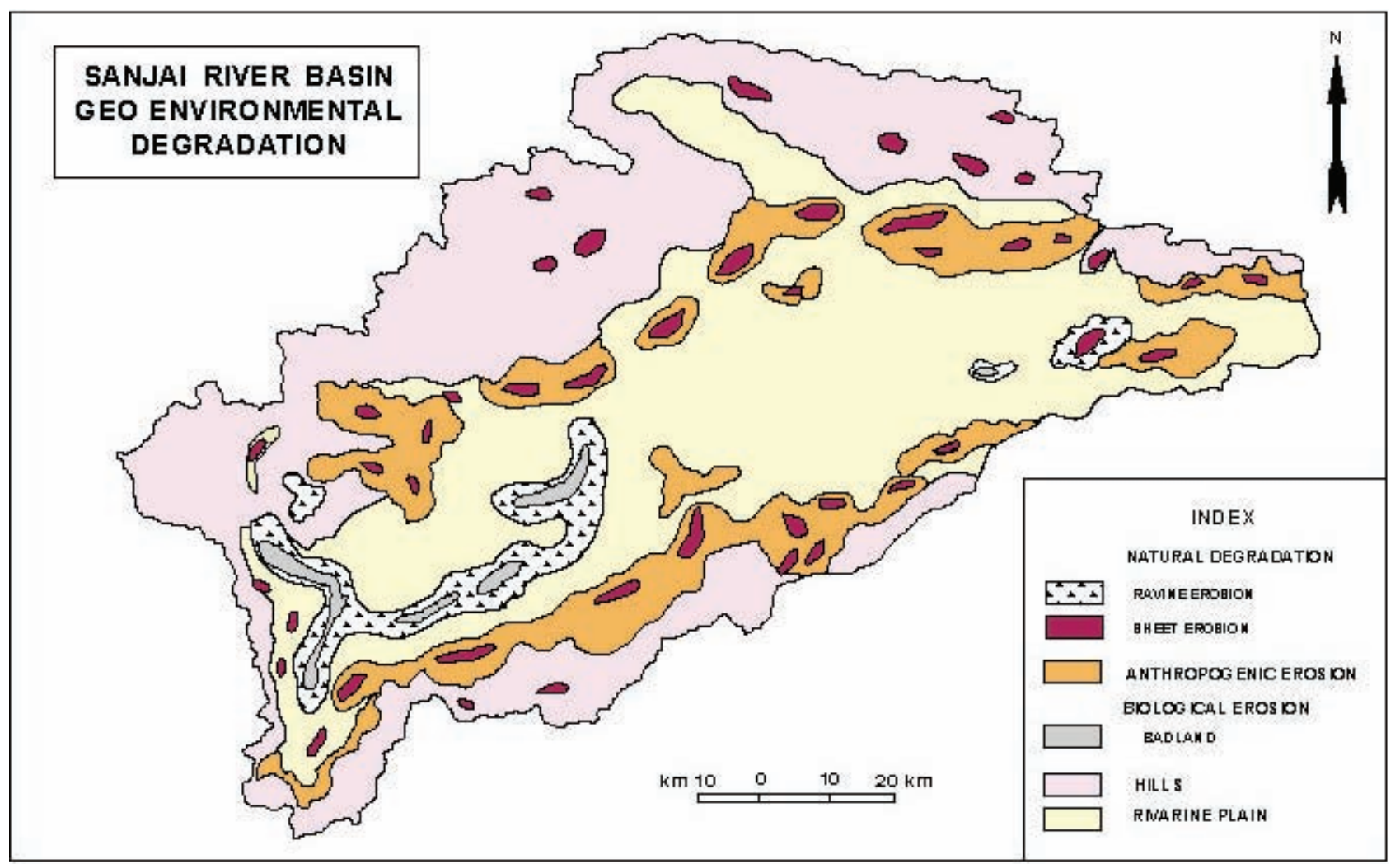

FIGURE 7: Sanjai River Basin - Geo environmental degradation

\section{- Important features of Ravine erosion}

Ravine erosion is more prominent in the relatively level or undulating surface than on the steeper slopes.

The hilly areas are free from ravine erosion for example Porahat and Dalma hills due to their general inaccessibility to man and livestock and dense forest. Another cause is some hilly areas are so steep and rocky that soil and sediments are totally absent. So there is no possibility of ravine erosion. On this steeper slopes hard rock prevents ravine erosion (quartzite, basalt etc.).

Ravine erosion is found in the basin where the slope is very gentle and thinly covered by vegetation or removed by men and livestock (FIGURE 6).

\section{- Sheet Erosion}

Sheet erosion is generally found in sloping deforested land of the basin mostly in western and southwestern hilly part and southern hilly part of the 
basin. It prevails in the deforested upland and hilly areas. In the basin area there are numerous protected forests where the sheet erosion is checked by dense forest. outside of those prohibited area severe erosion prevails due to ruthless cutting of trees and shifting of cultivation. Sheet erosion is very prominent in village uplands or on the dungris (small hill).

\section{- Anththropological Degradation}

Anthropogenic degradation of the basin is very high. Anthropogenic activities include construction of dams, irrigation canals, deforestation, leading to accelerated soil degradation through salinization, flooding, draught, erosion, water logging etc. affecting the land and reducing agricultural productivity. It is pronounced in central part with low slope, northern and western upland parts and small patches of the southern hilly areas.

\section{- Biological Degradation}

Badlands are formed due to biological degradation. It means heavily gullied and ravinated land (SINGH, 1998). Mostly developed in the southwestern part of the basin but some small patches are also found in eastern parts of the basin.

\section{INTEGRATED ENVIRONMENTAL MANAGEMENT}

Following measures may be considered to rehabilitate and to restore and minimize the Land Degradation processes for having Integrated Management of the Study-Area.

Integrated plan for eco-tourism in typical landforms conserving existing resources and cultural heritage and rational economic viability (Development of Geo-Touristic Sites in the Erosion Surfaces of the Study-Area.

Development of small scale industry of using forest products.

Mobilisation of farmer and local people to improve agricultural(particularly rainfed) and non agricultural productivity by training program on location specific degrading laterite terrain.

More considerations of traditional vegetative measure or bionomic for bringing back forest which was originally absent (aforestation) or originally present(deforestation), agro-forestry, social-forestry.

Mechanical measures not by replacing vegetative measure totally instead by designing to supplement vegetation in process of excessive soil degradation through "contour furrowing or contour bunding and structural measures to divert run off where it can be safely disposed -to reduce velocity of runoff by effective barrier - improvement of catchment of gully of varying size - stabilization of gully head except those having a small drainage area. by earth plugs(a series of earth fills placed across small or medium gullies) maintaining space according to water level of earth dam upstream to channel bottom. - Check dam(temporary not more than $0.5 \mathrm{~m} \mathrm{high/permanent-}$ gully head check dam-reinforced concrete masonary) in small/medium/large gullies if water can not be kept out of gullies by either infiltration in the soil or by diversion .Degrading gully heads to check the gully from scouring backward by riprap inter-planted with cutting, brush cover etc.

Appropriate landuse practice for arresting land degradation and desertification.

Coverage of sisal plants/date palm/and other local semi-xerophytic.

Natural vegetation species in commercial scale - double multiple benefit of : Land Quality Protection, small scale / household industry raw material production, employment generation, widening of economic opportunity.

Landuse planning on micro watershed basis along with dryland farming suitable in such degraded area(Groundnut, Oil seeds, Jowar, Bazra, MaizHYV)).

Organisation of commercially important herbal and medicinal plants which belong to this region as part of natural vegetation to promote alternative avenues of economic sustanability.

Gully Management for planning and development of the Gully-eroded area.

To suggest measures for slowing down the natural degradation \& desertification. processes and focus on anthropogenic elements that instigate the above two processes - preventive and curative methods. 


\section{REFERENCES}

AGARWAL, R. P. Geomorphology and Evolution of West Coast of India Between Mangalore and Kanyakumari - A Remote Sensing Prospective, Indian Journal of Geomorphology, Academic \& Law Serials, vol.4., p. 67-74, 1999.

AGARWAL, R. P.; MITRA, D. S. Remote sensing in Geomorphology - An overview with Case Studies. Indian Journal of Geomorphology, Academic \& Law Serials, vol. 4, p. 93-102, 1999.

BERGER. Geoindicators - A potential tool for assessing geological change in the Indian Landscape, Geoenvironmental Indicators, Delhi, Abstruct volume, 1997.

BHAMERE, S. M.; VAISAMPAYAN, M. R. Granulometric Approach to Reconstruct the Palaeoenvironment of lower Amarawati Flood plain, Indian Journal of Geomorphology, vol. 9, p. 1-16, 2004.

COATES, D.R. Environmental Geomorphology and Landscape Conservation, vol. 1, Dowden,Hutchinson and Ross, Stroudsbury, 1972. p.1-13.

DUEL, H. Bio geomorphological development of flood plain (Rhine \& Meuse River), Project Report (internet version) 2004. Available in: $<\mathrm{http}: / /$ www.onderzoekinformatie.nl/en/oi/nod/onderzoek/ OND1279099/>.

GUPTA, S. K. Research Priorities in Soil Science for the Future: Some Thoughts, Geographical Review of India, Geographical Society of India , Kolkata, vol. 66, n. 2, p. 102-114, 2004.

JHA, V.C. Denudational Processes and landforms characteristics in the laterites of the Birbhum district. Transactions, West Bengal, India, Pune, vol 27, n. 1, p. 19-29, 2005.

. Engineering geomorphology, In: GOUDIE, A. (Ed) Encyclopedia of geomorphology. New York \& London: Routledge Publications, 2003. p. 316-318.
. Land degradation and desertification. Jaipur and New Delhi: Rawat Publications, 2003.

MILLER, C. E.; TURK, L. M. Fundamentals of Soil Science, John Wiley \& Sons, New York, p. 45-80, 1954.

RANJIT, R. Geomorphic Signatures of Ore Deposits- A case study From Sukinda Chromite and Nickel Complex, Orissa, Journal of The Indian Society of The Remote Sensing, Indian Society of Remote Sensing, IIRS Campus, Dehra Dun, vol. 31, n.2, p. $107-$ 118., 2003.

SAXENA, H. M., Environmental Geography. Jaipur: Rawat Publications, 2004. p. 58-91 and 245-292.

Scheidegger, A. E. (1976), Foundations of Geophysics, Elsevier Scientific Publishing Company, Amsterdam., pp. 162-184.

SEHGAL, J., ABROL, I. P. Soil Degradation in India: Satus and Impact, Oxford and IBH Publishing Co., New Delhi, p. 14-15, 2000.

SHARMA, S. D. Geomorphometric Variation Index: An Appoach For Evaluation Of Environmental Degradation, Indian Journal of Geomorphology, Academic and Law Serial, New Delhi, p. 81-88, 2002.

SINGH, R.; PHADKE,V. S. Assesing Soil Loss by Water Erosion in Jamni River Basin, Bundelkhand Region, India, Geographical Review of India, The Geographical Society of India, Kolkata, vol. 66, n. 2 , p. 131-142, 2004.

SINGH, S. Anthropogenic Geomorphology, Man and Geomorphological Processes, Indian Journal of Geomorphology, Academic \& Law Serials, Delhi, vol. 5, n. 1\&2, p. 101-110, 2000.

SINGH, V. P. Erosion Surface of Patlands of Chotanagpur Region, India, Indian Journal of Geomorphology, Academic \& Law Serials, vol. 5, n. 1-2, p. 55-62, 2000. 